University of Nebraska - Lincoln

DigitalCommons@University of Nebraska - Lincoln

Faculty Publications from the Harold W. Manter Laboratory of Parasitology

10-1968

\title{
Zoonotic Diseases in the Changing Arctic
}

Robert L. Rausch

Arctic Health Research Center, rausch@u.washington.edu

Follow this and additional works at: https://digitalcommons.unl.edu/parasitologyfacpubs

Part of the Parasitology Commons

Rausch, Robert L., "Zoonotic Diseases in the Changing Arctic" (1968). Faculty Publications from the Harold W. Manter Laboratory of Parasitology. 537.

https://digitalcommons.unl.edu/parasitologyfacpubs/537

This Article is brought to you for free and open access by the Parasitology, Harold W. Manter Laboratory of at DigitalCommons@University of Nebraska - Lincoln. It has been accepted for inclusion in Faculty Publications from the Harold W. Manter Laboratory of Parasitology by an authorized administrator of DigitalCommons@University of Nebraska - Lincoln. 


\section{Zoonotic Diseases}

\section{in the \\ Changing Arctic}

Robert L. Rausch, PhD, College, Alasha
Compatible with the biotic uniformity of northern regions, the occurrence of certain organisms which cause zoonotic diseases is general throughout the Arctic. In the past, most frequently affected by such diseases have been aboriginal peoples whose way of life involved encroachment upon naturally occurring parasite-host assemblages. Now, as changes take place in socioeconomic conditions in the Arctic, the importance of zoonotic diseases as a cause of morbidity may lessen among such peoples, but on the other hand, more nonaborigines may be affected. Although my remarks relate mainly to Alaska, again the biotic uniformity of the North seems to have its effect even with regard to man's activity, for similar changes are occurring throughout the arctic zone.

With European exploration and colonization of the North American Arctic, many of the attending records of observations contain numerous references to communicable diseases of man, but little about those transmitted from other animals. For northern areas, the knowledge of zoonotic diseases has been mainly acquired during the past 20 years, with one notable exception: Before the arrival of Europeans in arctic North America, the aboriginal peoples were aware of the existence of at least two or three diseases transmissible from other animals. The Eskimos inhabiting the arctic coast of Alaska traditionally cooked the flesh of polar bears thoroughly, thereby avoiding infection by

Submitted for publication Aug 3, 1967; accepted Dec 12.

From the Zoonotic Disease Section, Arctic Health Research Laboratory, Public Health Service, College, Alaska.

Read before the Symposium on Circumpolar Health Related Problems, University of Alaska, College, Alaska, July 28, 1967.

Reprint requests to Zoonotic Disease Section, Arctic Health Research Laboratory, Public Health Service, College, Alaska 99701 (Dr. Rausch). 
Trichinella spiralis. That this practice had become established suggests the possibility that there was recognition of a relationship hetween the eating of uncooked hear meat and subsequent illness. Northern Alaskan and northeastern Siberian Eskimos have long recognized the occurrence of rabies in dogs and foxes. On St. Lawrence Island, where the people claim to have known that rabies was transmissible to man, rabid animals were killed as soon as their condition was recognized. In this region, the Eskimo word used to designate rabid animals (suumuk) is currently used also in reference to insanity and intoxication. The Eskimos of the Alaskan arctic coast also have a special word to designate rabid animals (malukali; malukaliruk kimik). Inland Eskimo hunters with their keen knowledge of the anatomy of caribou (wild reindeer) no doubt recognized as being abnormal the cysts of Echinococcus granulosus as well as lesions of other kinds in caribou. The Nunamiut Eskimo (Brooks Range) avoid the killing of animals which appear to be unhealthy. These people have a general term (kuaktit) for helminths occurring in man and other animals. Another of their words (kupilluguk) is now used to denote pathogenic microorganisms, but this term formerly had a broader application in reference to small organisms.

As medical scientists began observations in northern regions, definite documentation has accumulated regarding zoonoses. Rabies, or a rabies-like disease, has long been known to affect dogs and foxes in arctic North America. ${ }^{1,2}$ Hjortlund in 1906, ${ }^{3}$ in conclusions not then generally accepted, convincingly demonstrated experimentally the occurrence of rabies virus in animals in Greenland. Field observations made during the time of the Fifth Thule Expedition (1921 to 1924) led Freuchen ${ }^{4}$ to conclude that rabies was the most common disease of foxes in the central Canadian Arctic. Wells ${ }^{5}$ much later isolated the virus from animals from northern Canada. In Alaska, Ferenbaugh $^{6}$ first clinically diagnosed rabies in foxes, but it was not until 1949 that a laboratory diagnosis was made. ${ }^{7}$

The first indication that trichinellosis is an important disease in the Arctic was provided by the work of Thorborg et $a{ }^{8},{ }^{8}$ in Greenland.
Echinococcus granulosus was recorded in Alaska by Hadwen and Palmer in 1922," but not until 26 years later was a human case recorded..$^{10} E$ multilocularis has been recognized as a distinct species for little more than ten years. This cestode and the disease caused by it in man have been investigated intensively in recent years in Alaska, in Canada, and in the Soviet Union.

Tularemia in man in Alaska was definitely recorded by Williams. ${ }^{11}$ Earlier (1939), Philip ${ }^{12}$ described a suspected case of this disease.

Brucellosis is now recognized as a widely occurring disease of wild and domestic reindeer in Alaska, with diagnosis of a human case first reported in 1958.13 Earlier, in 1954, Corrigan and Hanson ${ }^{14}$ diagnosed brucellosis in an Eskimo from arctic Cana$\mathrm{da}$, suggesting at the time that caribou were the probable source of infection.

Rabies, trichinellosis, hydatid disease (both cystic and alveolar), tularemia, and brucellosis are among the most prevalent zoonoses in the Arctic, and knowledge of them is most complete. The status of various organisms known to be potentially pathogenic for man in the Arctic remains uncertain. Pasteurella pseudotuberculosis has been recorded once in south-central Alaska. Leptospira ballum has been isolated from the Alaska Peninsula (F. N. Woods, oral communication, 1967). Nordland ${ }^{15}$ isolated Listeria monocytogenes from wild animals in northern Canada. Serological findings indicate that man in the Arctic may be frequently infected by a virus of the ornithosis group. ${ }^{16,17}$ Serological studies have provided strong evidence of the presence of arboviruses in Alaska ( $R$. Berger, oral communication, 1967).

For the human population throughout the Arctic, changing social conditions will undoubtedly affect the pattern of occurrence of some of the zoonotic diseases. In Alaska, acculturation of the aboriginal peoples is already advanced, with assumption of the Caucasian way of life as rapidly as economic means permit. Among these people general$\mathrm{ly}$, the younger generations no longer are learning the skills essential for a hunting culture. Dwellings of the old style, well adapted to the arctic environment, have largely been replaced by frame houses of a 
sort better suited to conditions at lower latitudes. Motor-driven vehicles are replacing sled dogs. Processed foods, most of which are imported, are supplanting traditional diets.

In these early stages of cultural transition, the health of aboriginal peoples may be expected to deteriorate, as the following example will illustrate: The northern Alaskan Nunamiut Eskimo, traditionally nomadic until 1951, entered a transitional phase at about this time when a post office was established at Anaktuvuk Pass, followed by construction of a church and a school. Although they are still largely dependent upon hunting for their livelihood, the people have become increasingly sedentary. In former times, camp sites were abandoned when they became contaminated by excreta of dogs and other wastes, and only when the traces of earlier activity had disappeared were former sites reoccupied. The portable skin tents and other temporary dwellings used had floor coverings of willow branches through which debris settled. The permanent houses are more difficult to clean as is the permanent village site on which about 100 people and their approximately 200 essential dogs live. During the period 1948 to 1951 , one case of cystic hydatid disease was diagnosed among these people. Since the village was established, at least five new cases have been recognized; three patients were children, the youngest, 7 years old. In 1951, only two or three persons reacted positively to the tuberculin test; since then, several serious cases of tuberculosis have been diagnosed and treated. Enteric disorders, too, are evidently more prevalent. In this community, no new hygienic standards have yet firmly replaced former customs, but as sanitary conditions improve, zoonotic diseases will become less important as a cause of morbidity among these and other aboriginal peoples.

As their way of life changes, Indians and Eskimos will spend less time hunting and gathering locally available foods, and exposure to infection by pathogens occurring in nature will be significantly reduced. Changing dietary habits, particularly among younger people, also will have a marked effect, eg, a reduction in the amount of fish eaten raw would modify rates of infection by cestodes and other fish-transmitted hel- minths. Dietary habits may be influenced, again especially among younger individuals, by the attitudes of nonaborigines who frequently express revulsion toward certain aboriginal foods; for example, among the Nunamiut, few of the younger people will now eat the living larvae of nasal bots and warbles of reindeer, although such delicacies were much enjoyed less than 20 years ago. On the other hand, as nonaborigines inhabit the more remote areas in increasing numbers, they will be exposed to zoonotic diseases which are now rarely found among them in Alaska.

Not only do modern methods of transport provide increasing opportunity for the dissemination of pathogens within the Arctic, but an appreciable risk exists that exotic pathogens and their vectors may be introduced into northern regions. In spring, 1967, for example, a mouse-like rodent, Apodemus species, was found aboard a plane arriving at Anchorage, Alaska, from the Orient. The animal harbored living fleas, among which was Xenopsylla cheopis, an important vector of plague. Spread of ectoparasites and possible introduction of disease could be the result if such animals were to escape where rats and other rodents are present (Norway rats and house mice have become established in several towns in Alaska, as well as on some of the Aleutian Islands, and indigenous rodents are generally abundant). While plague is not a disease of rodents at higher latitudes, Pasteurella pestis might become established if introduced under favorable circumstances. One flea, at least, of an Alaskan rodent is a potential vector; the common flea of marmots in northern Alaska is Oropsylla silantiewi, which is an important vector of plague in eastern Eurasia.

Control of zoonotic diseases in arctic regions can best be achieved through education and improvement of the standard of living, but because some customs change only with difficulty, rapid progress is not to be expected. The artificial control of pathogens causing zoonoses is not practicable under conditions existing in the Arctic where animal life is abundant, and where diseases such as tularemia, pseudotuberculosis, and rabies can long persist undetected in natural hosts. Moreover, some diseases may be disseminated by widely ranging animals. For 
example, an arctic fox killed during the winter of 1966 on the ice island, T-3, when the island was about 700 miles north of the nearest land, was sent to us by the Arctic Research Iaboratory, Office of Naval Research, at Point Barrow. Rabies virus was isolated from the brain of this animal, and $E$ multilocularis was present in the small intestine. Experimentally, we have found that the incubation period of rabies in arctic foxes may be as long as six months. Such ambulatory, infected animals could travel considerable distances before becoming rabid, thus acting to disperse the virus and other organisms, and possibly occasionally introducing them on remotely situated islands or into other areas.

Thus far, the natural environment has not been extensively disrupted at higher lati- tudes, and the arctic regions remain important for basic research in the natural history of zoonotic diseases. Because of the biotic peculiarities of these regions, conditions there especially favor the investigation of parasite-host relationships and the transmission of disease among the inhabitants. Significant benefit to the human population, in the temperate zone as well, can be expected to accrue from future studies in an undisturbed arctic wilderness.

Dr. George P. Holland, director of the Entomology Research Institute, Department of Agriculture, Ottawa, identified numerous collections of fleas from Alaska, and provided the determinations for the species mentioned in the present paper. Dr. Max C. Brewer, scientific director of the Arctic Research Laboratory, Office of Naval Research, Point Barrow, provided numerous specimens for the study, including the arctic fox from the ice island, $T-3$.

\section{References}

1. Elton, C.: Epidemics Among Sledge Dogs in the Canadian Arctic and Their Relation to Disease in the Arctic Fox, Canad J Res 5:673-692, 1931.

2. Elton, C.: "Voles, Mice and Lemmings," in Problems in Population Dynamics, Oxford, England: Clarendon Press, 1942, 496 pp.

3. Braestrup, F.W.: A Study on the Arctic Fox in Greenland: Immigrations, Fluctuations in Numbers Based Mainly on Trading Statistics, Medd om Gronland 131:1-101, 1941.

4. Freuchen, P.: "Field Notes and Biological Observations," in Report of the Mammals Collected by the Fifth Thule Expedition to Arctic North America: Zoology I, By M. Degerbel and P. Freuchen. Report of the 5th Thule Expedition 1921-24, 2:1-278 (pt 2) 1935

5. Wells, K.F.: The Rabies Menace in Canada, Canad J Public Health 48:239-243, 1957.

6. Ferenbaugh, T.L.: A Note Concerning the Occurrence of Hydrophobia in the Foxes of Alaska, Milit Surg 38:656-657, 1916.

7. Williams, R.B.: Epizootic of Rabies in Interior Alaska 1945-47, Cunat d comp Med 12:136-143, 1949 .

8. Thorborg, N.B.; Tulinius, S.; and Roth, H.: Trichinosis in Greenland, Acta I'ath 25:778-794, 1948.
9. Hadwen, S., and Palmer, L.J.: Reindeer in Alaska, bulletin 1089, US Dept Agriculture, 1922, p 74.

10. Williams, R.B.: Echinococcosis or hydatid disease, Alaska's Health 6:6, 1948.

11. Williams, R.B.: Tularemia: First Case to be Reported in Alaska, Public Health Rep 61:875-876, 1946.

12. Philip, C.B.: Tularaemia in Alaska, Proc 6th Pacific Sci Congr 5:71-73, 1939.

13. Edwards, S.: Brucella suis in the Arctic, Alaska Med 1:41-44, 1959.

14. Corrigan, C., and Hanson, S.: Brucellosis and Miliary Tuberculosis in an Eskimo Woman, Canad Med Assoc o 72:217-218, 1955.

15. Nordland, O.S.: Host-Parasite Relations in Initiation of Infection: I. Occurrence of Listeriosis in Arctic Mammals, With a Note on its Possible Pathogenesis, Canad J Comp Med 23:393-400, 1959.

16. Hildes, J.A.; Wilt, J.C.; and Stanfield, F.J.: Antibodies to Adenovirus and to Psittacosis in Fastem Arctic Fskimos, Canad of Public Health 49:230-231, 1958.

17. Wilt, J.C.; Hildes, I.A.; and Stanfield, F.J.: The Prevalence of Complement-Fixing Antibodies Against Psittacosis in the Canadian Arctic, Canad Med Assoc J 81:731-733, 1959. 